\title{
Effects of Aspirin and Dipyridamole on the Degradation of Adenosine Diphosphate by Cultured Cells Derived from Bovine Pulmonary Artery
}

\author{
David J. Crutchley, Una S. Ryan, and James W. Ryan, Research Division, Miami \\ Heart Institute, Miami Beach, Florida 33140; Department of Medicine, \\ University of Miami School of Medicine, Miami, Florida 33101
}

A B S TRACT To improve understanding of the mechanisms by which ADP is degraded during passage through the pulmonary vascular bed, we examined cultured endothelial and smooth muscle cells of bovine pulmonary artery for their abilities to metabolize $\left[8-{ }^{14} \mathrm{C}\right] \mathrm{ADP}$. ADP is rapidly converted to AMP and then to adenosine, hypoxanthine, and inosine. Inosine is the major metabolite produced by endothelial cells. Radioactivity $(5-10 \%)$ is accumulated intracellularly primarily as ATP. Medium containing $50 \mu \mathrm{M}$ ADP incubated with endothelial cells rapidly loses its ability to aggregate platelets and becomes antiaggregatory under conditions in which prostacyclin is absent. The antiaggregatory activity is probably the result of accumulated adenosine. $10 \mu \mathrm{M}$ dipyridamole inhibits cellular uptake of radioactivity by $>90 \%$, and inosine in the medium is largely replaced by adenosine. This is accompanied by increased antiaggregatory activity of conditioned medium, which can be matched by authentic adenosine at the same concentration. $1 \mathrm{mM}$ aspirin had no effect on the metabolism of ADP by endothelial cells. Our results suggest: (a) Metabolism of ADP during passage through the lung is mainly the result of endothelial ADPase. $(b)$ ADP released from aggregating platelets can be converted to the antiaggregatory substance, adenosine. Dipyridamole may exert some of its antithrombotic actions by preventing the intracellular uptake of adenosine, thereby increasing its concentration near the site of thrombus formation. $(c)$ The ability of the vessel wall to degrade ADP should not be compromised by the use of aspirin as an antithrombotic drug. (d) Endothelium may retain some of its antithrombogenicity when prostacyclin generation is impaired.

Received for publication 24 September 1.979 and in revised form 18 February 1980.

\section{INTRODUCTION}

Although the lung can trap and remove large numbers of thromboemboli presented to it via the systemic circulation (1), uncontrolled platelet aggregation in the lung would rapidly prove fatal. At least two protective mechanisms appear to exist to prevent this. First, the lung may continuously produce antiaggregatory prostacyclin $\left(\mathrm{PGI}_{2}\right)^{1}(2-4)$; second, the pulmonary vessels possess an active ADPase that rapidly degrades the important mediator of platelet aggregation, ADP $(5,6)$. An additional function of pulmonary ADPase may be to prevent the entry of ADP into the systemic circulation, thereby complementing the postulated systemic antithrombotic functions of $\mathrm{PGI}_{2}$.

To determine more precisely the location of pulmonary vascular ADPase, we have examined the metabolism of ADP by cultured cells derived from bovine pulmonary artery. Our results show that both endothelial and smooth muscle cells rapidly metabolize ADP and produce antiaggregatory adenosine. We have also studied the effects of dipyridamole and aspirin, both of which are currently undergoing clinical trials as antithrombotic drugs (i.e., the Persantineaspirin reinfarction study). Dipyridamole was of particular interest because it inhibits the intracellular uptake of adenosine in several systems, including cultured endothelial cells $(7,8)$ and lung $(9,10)$. Our results provide additional information on the antithrombotic actions of dipyridamole and also suggest that the ability of the vessel wall to degrade ADP will not be compromised by the use of aspirin as an antithrombotic drug.

\section{METHODS}

Materials for the preparation of cell culture medium were obtained from Gibco Laboratories, Grand Island Biological Co.,

\footnotetext{
${ }^{1}$ Abbreviation used in this paper: $\mathrm{PGI}_{2}$, prostacyclin.
} 
Grand Island, N. Y. Collagenase was obtained from Worthington Biochemical Corp., Freehold, N. J. $\left[8-{ }^{14} \mathrm{C}\right] \mathrm{ADP}$, sp act $39 \mathrm{mCi} / \mathrm{mmol},\left[8-{ }^{14} \mathrm{C}\right]$ adenosine, sp act $54 \mathrm{mCi} / \mathrm{mmol}$, and Riafluor scintillator were obtained from New England Nuclear, Boston, Mass. Unlabelled purines, aspirin, and trypsin were obtained from Sigma Chemical Co., St. Louis, Mo. Aluminum-backed plates for thin-layer chromatography, coated with $0.2 \mathrm{~mm}$ silica gel containing fluorescent indicator, were manufactured by Merck AG, Darmstadt, West Germany. Rabbit antiserum to human Factor VIII-associated protein, and rabbit antiserum to human $\alpha_{2}$-macroglobulin were obtained from Behring Diagnostics, Inc., Woodbury, N. Y. Fluorochrome-conjugated goat antiserum to rabbit immunoglobulin (Ig)G was obtained from Miles-Yeda, Miles Laboratories Inc., Elkhart, Ind. $\left[{ }^{3} \mathrm{H}\right]$ Benzoyl-Phe-Ala-Pro$\mathrm{OH}$ was used as the substrate for angiotensin-converting enzyme assay and was synthesized as described (11).

Cell culture. Endothelial cells were obtained by treatment of bovine pulmonary arteries with $0.2 \%$ collagenase (12). Smooth muscle cells were obtained from the same vessels (13). Cells were growth in Eagle's minimal essential medium containing $2 \mathrm{mM}$ L-glutamine and supplemented with $20 \%$ heat-inactivated $\left(56^{\circ} \mathrm{C}\right.$ for $\left.30 \mathrm{~min}\right)$ fetal calf serum, $50 \mu \mathrm{g} / \mathrm{ml}$ streptomycin, $50 \mathrm{U} / \mathrm{ml}$ penicillin, $100 \mu \mathrm{g} / \mathrm{ml}$ fungizone, and $100 \mu \mathrm{g} / \mathrm{ml}$ kanomycin.

Criteria for the morphological and biochemical characterization of our endothelial cell cultures have been described in detail previously (12). Endothelial cells grew as contactinhibited monolayers with a "cobblestone" morphology. Electron microscopic examination of thin sections indicated large numbers of caveolae, occasional Weibel-Palade bodies, and the full complement of organelles characteristic of endothelial cells in situ. The cells were reactive with antibodies to human Factor VIII and human $\alpha_{2}$-macroglobulin, as indicated by indirect immunofluorescence (12). The endothelial monolayers possessed angiotensin-converting enzyme activity assayed with $\left[{ }^{3} \mathrm{H}\right]$ benzoyl-Phe-Ala-Pro-OH $(11,12)$ Primary cultures, at least $98 \%$ endothelial by inspection in the inverted microscope, were purified by differential adherence techniques over the 1st-3rd passages $(12,14)$. Endothelial cultures used for the experiments described in this paper were from the 4 th-9th passages, thus eliminating the possibility of contaminating cell types such as smooth muscle or fibroblasts. All cultures were examined by phase microscopy before use. Smooth muscle cells were larger and flatter than endothelial cells, contained dense bodies, and grew to form characteristic "ridges" (13).

Incubations. Confluent layers of cells in $35-\mathrm{mm}$ dishes $\left(\sim 3 \times 10^{5}\right.$ cells $/$ dish $)$ were incubated with a $1 \mathrm{ml}$ serum-free medium containing $50 \mu \mathrm{M}\left[8-{ }^{14} \mathrm{C}\right] \mathrm{ADP}, 0.5 \mu \mathrm{Ci} / \mathrm{ml}$, or 20 $\mu \mathrm{M}\left[8-{ }^{14} \mathrm{C}\right]$ adenosine, $0.25 \mu \mathrm{Ci} / \mathrm{ml}$. Incubations were performed in triplicate. After suitable incubation times, the medium was removed, centrifuged ( $900 \mathrm{~g}, 5 \mathrm{~min})$ to sediment any detached cells, and the supernate incubated at $37^{\circ} \mathrm{C}$ for 30 min to allow spontaneous degradation of $\mathrm{PGI}_{2}(15,16)$. No degradation of ADP was observed when added to dishes without cells and incubated at $37^{\circ} \mathrm{C}$ for $60 \mathrm{~min}$. Cells were washed three times with ice cold saline A solution containing $20 \mathrm{mM}$ Hepes, $\mathrm{pH} 7.4$, and then extracted with $0.5 \mathrm{ml}$ of $0.4 \mathrm{~N}$ perchloric acid. To investigate a possible extracellular release of ADPase, endothelial cells were incubated for $1 \mathrm{~h}$ with serum-free medium. This was then removed, centrifuged, and the supernate was incubated with $50 \mu \mathrm{M}$ $\left[8-{ }^{14} \mathrm{C}\right] \mathrm{ADP}$ for up to $1 \mathrm{~h}$. For aspirin studies, endothelial cells were incubated for $1 \mathrm{~h}$ with serum-free medium containing $1 \mathrm{mM}$ aspirin. The medium was discarded and the cells were washed several times with fresh serum-free medium before incubation with ADP. For dipyridamole studies, the drug was dissolved according to the manufacturer's instructions and added to cells simultaneously with ADP.

Thin-layer chromatography. Aliquots of conditioned medium or cell extracts were applied to silica gel plates containing a fluorescent indicator. Authentic ATP, ADP, AMP, adenosine, inosine, hypoxanthine, and adenine were applied to the plates as standards. The plates were developed in the system isobutyl alcohol/amyl alcohol/ethylene glycol monoethyl ether/ammonia/water, 45:30:90:45:60 (17). Typical $R_{f}$ values obtained with a solvent front height of $18 \mathrm{~cm}$ were: ATP 0.18, ADP 0.29, AMP 0.43, inosine 0.63, hypoxanthine 0.72 , adenosine 0.74 , adenine 0.84 . Better separation of nucleosides and bases was obtained by chromatography of samples in the solvent system $n$-butanol/ethyl acetate/methanol/ammonia, 7:4:3:4(18). Typical $R_{f}$ values obtained with this system were: inosine 0.23 , hypoxanthine 0.49 , adenosine 0.56 , adenine 0.69 , whereas $\mathrm{ATP}, \mathrm{ADP}$, and $\mathrm{AMP}$ remained at or near the origin. Standards were visualized under ultraviolet light, and appropriate zones were cut out and transferred to scintillation vials. The purines were eluted with $1 \mathrm{ml}$ water, Riafluor was added, and radioactivity was determined in a liquid scintillation counter. Recovery of radioactivity from the plates was routinely $>90 \%$ of that applied.

Platelet aggregation. Venous blood from human volunteers was anticoagulated with one ninth vol $110 \mathrm{mM}$ trisodium citrate, centrifuged at $200 \mathrm{~g}$ for $10 \mathrm{~min}$ to obtain platelet-rich plasma (PRP), and then further centrifuged at $1000 \mathrm{~g}$ for $20 \mathrm{~min}$ to obtain platelet-poor plasma. Platelet aggregation was determined turbidometrically (19) using a Bio/Data aggregometer (Bio/Data Corp., Willow Grove, Pa.). For calculation of apparent ADP concentration in conditioned medium, samples were diluted with fresh medium so that $50 \mu \mathrm{l}$ of the mixture added to $450 \mu$ l platelet-rich plasma gave only primary (reversible) aggregation, which was compared with the aggregation obtained with authentic ADP. The lowest concentration of ADP that could be detected in medium was $2 \mu \mathrm{M}$.

\section{RESULTS}

Metabolism of ADP and adenosine by pulmonary artery endothelial and smooth muscle cells. Incubation of ADP with endothelial cells led to a time-dependent reduction in the concentration of nucleotide in the cell medium, concomitant with a decrease in the ability of the medium to aggregate platelets (Fig. 1). The estimated half-life of $50 \mu \mathrm{M}$ ADP in $1 \mathrm{ml}$ incubated with $\sim 3 \times 10^{5}$ cells was 9 min at this substrate concentration, representing a rate of metabolism of $\sim 2.8$ $\mathrm{nmol} / \mathrm{min}$ per $3 \times 10^{5}$ cells. Analysis of cell medium showed that the disappearance of ADP was accompanied by the appearance of AMP, which reached a peak at $\sim 15 \mathrm{~min}$, and adenosine, which reached a plateau at $\sim 15 \mathrm{~min}$ (Fig. 2A). Hypoxanthine and inosine were also formed, and their concentrations increased throughout the incubation. Inosine was the major product after $30 \mathrm{~min}$ incubation. ATP and adenine were not detected in cell medium. Examination of perchloric acid extracts indicated a time-dependent accumulation of intracellular radioactivity, which at $60 \mathrm{~min}$ reached $5-10 \%$ of the total label. Between 65 and $75 \%$ of this material was ATP, the re- 


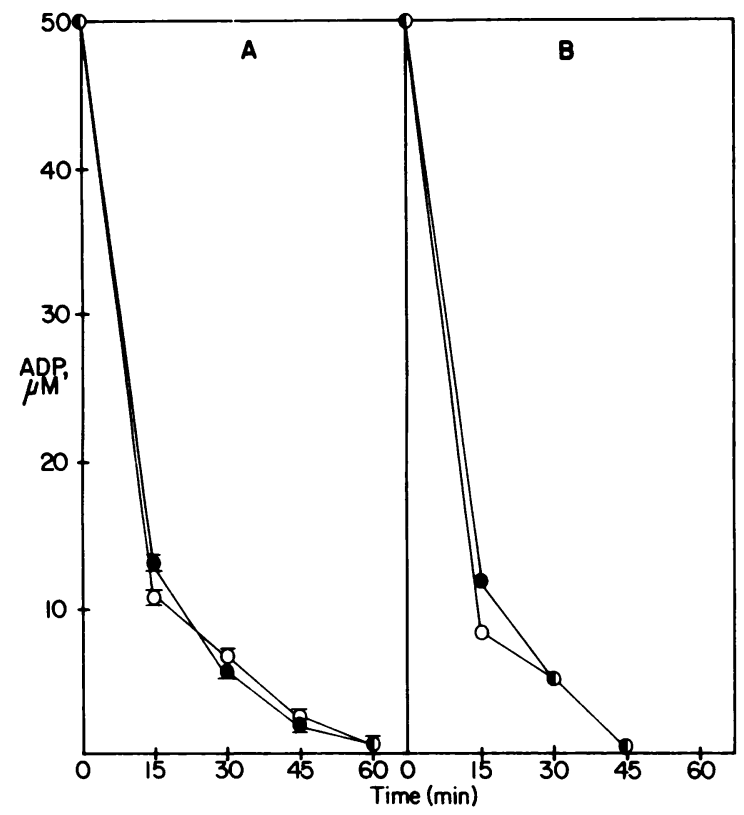

FIGURE 1 Metabolism of ADP by bovine pulmonary artery endothelial cells. Cells were preincubated for $60 \mathrm{~min}$ with $1 \mathrm{mM}$ aspirin $(O)$ or vehicle $(O)$, and then incubated with 50 $\mu \mathrm{M}\left[8-{ }^{14} \mathrm{C}\right] \mathrm{ADP}$ for the times shown on the abscissa. Concentrations of ADP in cell medium were assayed by thinlayer chromatography (A) or platelet aggregation (B). In the latter assay, samples were diluted to give primary aggregation only, which was compared with that obtained with authentic ADP. Each point is the mean $\pm S E$ of triplicate incubations (A) or the mean of duplicate incubations (B).

mainder being ADP and AMP. The pattern of intracellular metabolites is similar to that observed after uptake of adenosine into porcine endothelial cells (8). ADPase was not released from cells into the medium; $<2 \%$ of ADP was metabolized during a 1-h incubation with medium that had been preincubated for $1 \mathrm{~h}$ with endothelial cells. When endothelial cells were incubated with $20 \mu \mathrm{M}\left[8-{ }^{14} \mathrm{C}\right]$ adenosine, intracellular radioactivity reached $16 \%$ of total label after $60 \mathrm{~min}$, and adenosine in the cell medium was progressively replaced by inosine with smaller amounts of hypoxanthine. ATP, ADP, and AMP were not detected in cell medium in these studies (data not shown).

Pulmonary artery smooth muscle cells metabolized ADP at almost the same rate as endothelial cells (Fig. 2B). The major metabolite produced by smooth muscle cells was adenosine.

Effects of aspirin and dipyridamole on ADP metabolism by endothelial cells. Preincubation of cells for $60 \mathrm{~min}$ with $1 \mathrm{mM}$ aspirin had no effect on their ability to metabolize ADP, which was measured both chromatographically and by platelet aggregation (Fig. 1). Aspirin also had no effect on the subsequent production of metabolites. This relatively high dose of aspirin abolishes $\mathrm{PGI}_{2}$ production by endothelial cells

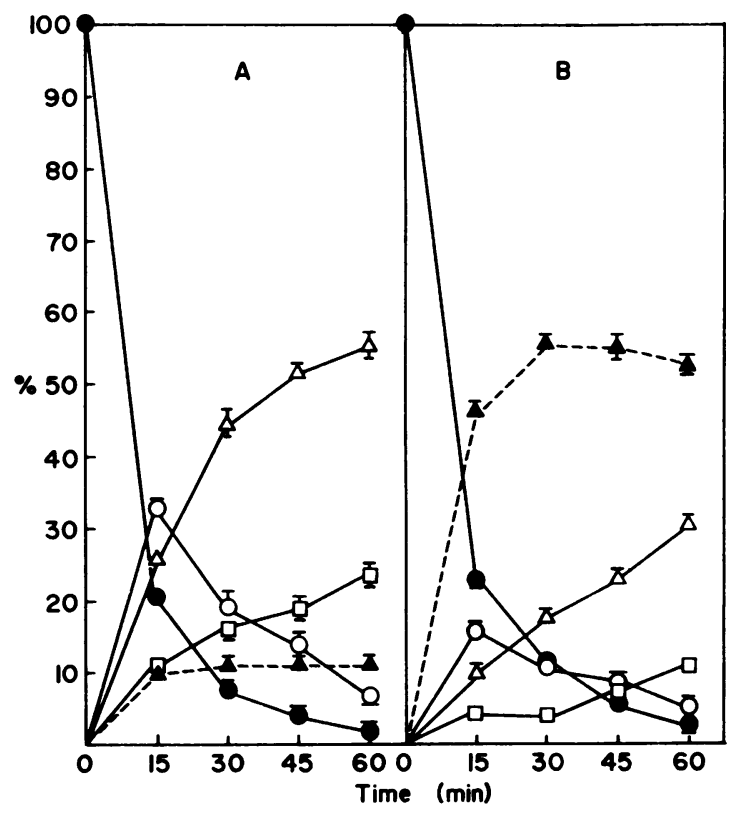

FIGURE 2 Profile of metabolites produced from ADP by bovine pulmonary artery endothelial and smooth muscle cells. Endothelial cells (A) or smooth muscle cells (B) were incubated with $50 \mu \mathrm{M}\left[8-{ }^{14} \mathrm{C}\right] \mathrm{ADP}$. Analysis of cell medium revealed ADP $(O)$, together with AMP (O), adenosine $(\Delta)$, inosine $(\triangle)$, and hypoxanthine $(\square)$. Each point is the mean $\pm S E$ of triplicate determinations.

derived from porcine aorta (20) and human umbilical vein (21), and abolishes prostaglandin production by bovine pulmonary artery endothelial cells (unpublished observations). ADPase in rat pulmonary vessels is similarly unaffected by high doses of aspirin (5). Therefore, these results suggest that the ability of endothelium to degrade ADP can be maintained when $\mathrm{PGI}_{2}$ production is seriously impaired.

Dipyridamole produced an apparent stimulation of ADPase because medium from endothelial cells incubated with ADP plus $10 \mu \mathrm{M}$ dipyridamole lost its platelet aggregating ability more rapidly than corresponding medium from cells incubated with ADP alone (Fig. 3). However, chromatographic analysis indicated that dipyridamole had no effect on the degradation of ADP but, rather, significantly altered the pattern of metabolites subsequently produced (Fig. 4). In the presence of dipyridamole, intracellular radioactivity was reduced by $>90 \%$, and inosine and hypoxanthine in the medium were reduced by $80 \%$, being replaced by adenosine, which became the major product. When dipyridamole-treated cells were incubated with $20 \mu \mathrm{M} \quad\left[8-{ }^{14} \mathrm{C}\right]$ adenosine, intracellular radioactivity was also reduced by $>90 \%$, and inosine and hypoxanthine in the medium were reduced by $70 \%$. The effects of dipyridamole were rapidly reversible; no effects were observed when cells were 


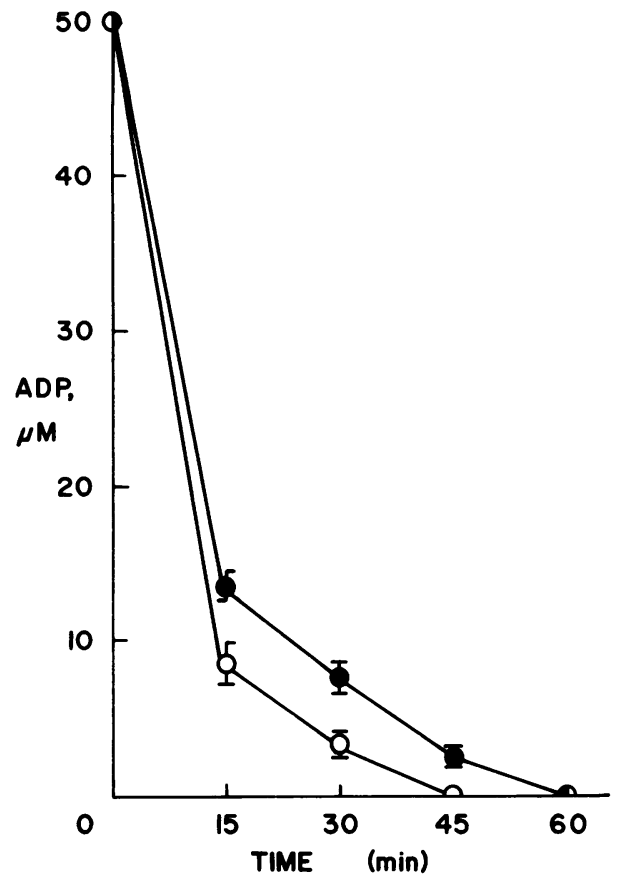

FIGURE 3 Effect of dipyridamole on metabolism of ADP by endothelial cells. Cells were incubated with $50 \mu \mathrm{M}\left[8-{ }^{14} \mathrm{C}\right]-$ ADP (O) or ADP plus $10 \mu \mathrm{M}$ dipyridamole (O). At the times shown, medium was removed, treated to degrade $\mathrm{PGI}_{2}$, and added to PRP. The ordinate shows apparent concentration of ADP in medium calculated by reference to a standard curve. Each point is the mean $\pm S E$ of triplicate incubations.

incubated for $60 \mathrm{~min}$ with 50-100 $\mu \mathrm{M}$ dipyridamole, washed, and then incubated with ADP.

Adenosine inhibits ADP-induced platelet aggregation, but hypoxanthine and inosine do not (19). The apparent stimulation of ADPase produced by dipyridamole, which was observed in the platelet assay, may therefore have been the result of the accumulation of adenosine at the expense of hypoxanthine and inosine. Consistent with this hypothesis is the finding that medium from cells incubated for $60 \mathrm{~min}$ with ADP plus dipyridamole was directly antiaggregatory under conditions in which $\mathrm{PGI}_{2}$ was absent (Fig. 5). Chromatographic analysis indicated that the concentration of adenosine in these samples was $\sim 30 \mu \mathrm{M}$. Fig. 5 also shows that $30 \mu \mathrm{M}$ authentic adenosine possessed the same inhibitory activity as conditioned medium. Moreover, medium from cells incubated for $60 \mathrm{~min}$ with ADP alone was weakly antiaggregatory, which is consistent with the lower concentrations of adenosine present in this medium. These results cannot be explained in terms of dipyridamole in the incubation medium being carried over into the platelet assay because untreated medium containing $10 \mu \mathrm{M}$ dipyridamole had no effect on the response of platelets to ADP. The increased antiaggregatory properties of

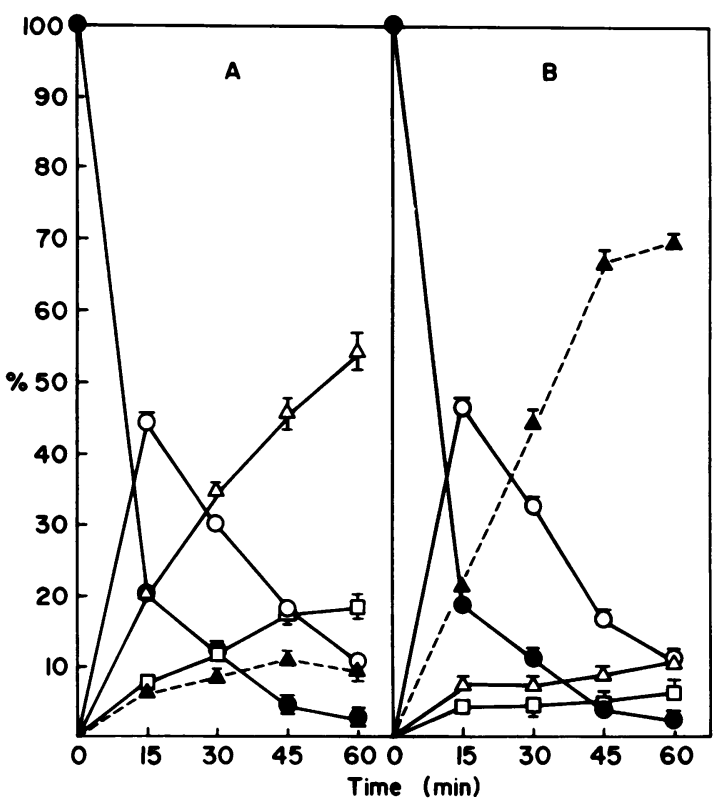

FIGURE 4 Thin-layer chromatographic analysis of samples used in Fig. 3. Cells were incubated with $50 \mu \mathrm{M}\left[8-{ }^{14} \mathrm{C}\right] \mathrm{ADP}$ (A) or ADP plus $10 \mu \mathrm{M}$ dipyridamole (B). Cell medium contained ADP $(\Theta)$, AMP $(O)$, adenosine $(\Delta)$, inosine $(\Delta)$, and hypoxanthine ( $\square$ ). Each point is mean $\pm \mathrm{SE}$ of triplicate incubations.

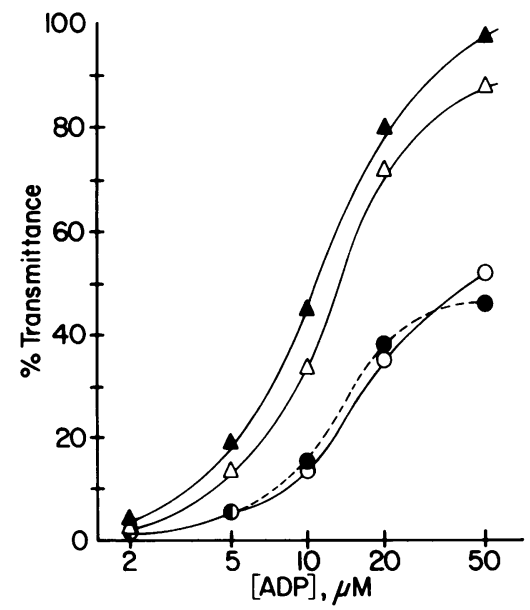

FIGURE 5 Inhibition of platelet aggregation by medium derived from endothelial cells incubated with ADP and dipyridamole. To $450 \mu \mathrm{l}$ PRP, $50 \mu$ l of each of the following was added: serum-free medium with or without $10 \mu \mathrm{M}$ dipyridamole $(\Delta)$, serum-free medium containing $30 \mu \mathrm{M}$ adenosine (๑), conditioned medium from cells incubated for $60 \mathrm{~min}$ with $50 \mu \mathrm{M}\left[8{ }^{-14} \mathrm{C}\right] \mathrm{ADP}(\triangle)$, and corresponding medium from cells incubated with ADP plus $10 \mu \mathrm{M}$ dipyridamole $(O)$. Aggregation was then initiated by the addition of $50 \mu \mathrm{l}$ standard ADP of the concentrations shown on the abscissa. The ordinate shows the maximum aggregation reached 2 min after addition of standard ADP. Each point is the mean of duplicate determinations. 
medium derived from dipyridamole-treated cells was, therefore, most likely the result of elevated levels of adenosine. However, these experiments do not rule out the possibility that endothelial cells produced an as yet unidentified, nonlabile inhibitor of aggregation when treated with dipyridamole.

\section{DISCUSSION}

Adenosine-5'-diphosphate is almost completely metabolized during a single passage through the pulmonary circulation, the initial step being catalyzed by an ADPase located at or near the lumen of the blood vessels (5). The present studies show that endothelial cells derived from bovine pulmonary artery rapidly metabolize ADP, the estimated initial rate being $\sim 2.8$ $\mathrm{nmol} / \mathrm{min}$ per $3 \times 10^{5}$ cells, at a substrate concentration of $50 \mu \mathrm{M}$. If the endothelial cells of the capillary bed possesses similar activity, their enormous numbers (at least $10^{11}$ cells in the pulmonary capillary bed of humans), together with their direct contact with circulating blood, suggest that the pulmonary endothelium should be capable of degrading ADP at a rate of $\sim 14$ $\mu \mathrm{mol} / \mathrm{s}$. Although extrapolation from data obtained with cultured cells to the situation obtaining in vivo may be difficult, our results nevertheless suggest that endothelial cells can fully account for the disappearance of ADP during passage through the pulmonary circulation. Similar calculations suggest that uptake into endothelium can account for the removal of adenosine by the pulmonary vascular bed (8). Our results show that smooth muscle cells also rapidly metabolize ADP. The significance of this is not clear, although smooth muscle ADPase may become relatively more important after damage to the vessel wall. ADPase activity is present in human venous endothelial cells and skin fibroblasts $(22,23)$ and in porcine aortic smooth muscle cells (6), but apparently not in human venous smooth muscle cells (22) or HeLa cells (unpublished observations).

The nature and time course of product formation suggest that the metabolism of ADP by pulmonary artery endothelial cells proceeds as follows: ADP is converted extracellularly to AMP and then to adenosine. This probably proceeds through the sequential action of ADPase and 5'-nucleotidase. However, the specificity of endothelial ADPase is not yet determined; hence, ADPase may contribute to the metabolism of AMP. Adenosine is taken up into the cell, and at these concentrations a minor portion is incorporated into nucleotides, whereas the remainder is deaminated to inosine. Inosine, in turn, may be converted to hypoxanthine by the action of nucleoside phosphorylase. Both inosine and hypoxanthine are released extracellularly. Inosine is the major product in lungs perfused with ADP or adenosine $(5,10)$ and may protect the pulmonary vessels against hypoxia (24).
The cellular distribution of the nucleotide-degrading enzymes would seem to support this scheme. Studies using homogenates of our endothelial cells and rabbit aortic cells have shown that ADPase activity occurs in fractions enriched with 5 '-nucleotidase and angiotensin-converting enzyme, both of which are localized to the plasma membrane (25-27). Adenosine deaminase is generally considered to be intracellular, as is nucleoside phosphorylase (28). The changes in metabolite distribution observed with dipyridamole (Fig. 4), which at $10 \mu \mathrm{M}$ inhibits adenosine uptake but not adenosine deaminase $(29,30)$, further support this scheme of ADP metabolism.

The potent antiaggregatory and disaggregatory properties of $\mathrm{PGI}_{2}$, together with its postulated continuous release into the circulation $(2-4)$, have led to the suggestion that $\mathrm{PGI}_{2}$ is a major mechanism whereby healthy vessels maintain their antithrombogenicity. However, under conditions where controlled platelet aggregation is necessary, i.e., to effect repair of a damaged vessel, an active ADPase may contribute to the desired fine control of hemostasis. Furthermore, the opposing actions of ADP and adenosine on platelet aggregation suggest that a balance between ADPase, 5 '-nucleotidase, and the adenosine-metabolizing system may also significantly influence thrombus formation. This concept is reinforced by the recent finding that cultured porcine endothelial cells selectively release adenine nucleotides when exposed to thrombin or mechanical trauma (31). The release leads initially to an extracellular accumulation of ADP, which is then converted via AMP to adenosine. Our results show that the nucleotidase system of endothelial cells is not inhibited by a relatively high dose of aspirin, suggesting not only that the ability of the vessel wall to degrade ADP will not be compromised by the use of aspirin as an antithrombotic drug, but also that endothelium may retain at least some of its antithrombogenicity when $\mathrm{PGI}_{2}$ production is seriously impaired.

The results obtained with dipyridamole are particularly interesting. Although this drug at concentrations of $50 \mu \mathrm{M}$ or more directly inhibits ADP-induced platelet aggregation and thromboxane synthesis (32), blood levels in vivo are unlikely to exceed $10 \mu \mathrm{M}$ (33). Clearly, the effects of dipyridamole in vivo are not explained by these actions. Moncada and Korbut (34) have recently postulated that the antithrombotic actions of dipyridamole are the result of synergism between its phosphodiesterase-inhibiting property and the adenyl cyclase-stimulating property of $\mathrm{PGI}_{2}$, resulting in elevated levels of platelet cyclic adenosine- $3^{\prime}$, 5 '-monophosphate. The observation that $2 \mu \mathrm{M}$ dipyridamole can inhibit platelet phosphodiesterase (32) supports their hypothesis. However, in these studies, antithrombotic activity was assessed in terms of reversal of platelet build-up on tendons superfused with 
blood in an extracorporeal circulation. Modulation of platelet aggregation by vessel walls in close contact with the thrombus would, therefore, not be detected in this model. Our results suggest an additional explanation of the antithrombotic actions of dipyridamole. ADP released by aggregating platelets is converted via vessel wall nucleotidases to adenosine, which in turn is taken up and further metabolized. Dipyridamole may elevate the concentration of adenosine in the region of the thrombus by blocking adenosine uptake by endothelial cells and also by platelets. Potentiation of the platelet inhibitory action of adenosine by dipyridamole may also occur (35).

Aspirin has recently received attention as a potential antithrombotic drug. However, it may be difficult to select a dose that will inhibit platelet thromboxane synthesis while leaving vascular $\mathrm{PGI}_{2}$ synthesis unimpaired (36). Given the difficulties of extrapolation from an in vitro system to conditions obtaining in vivo, our results nevertheless suggest that dipyridamole given in combination with aspirin may be desirable not only to render platelets more sensitive to $\mathrm{PGI}_{2}$ but to enhance the antithrombotic potential of the endothelial ADPase system should $\mathrm{PGI}_{2}$ synthesis be impaired.

\section{ACKNOWLEDGMENTS}

We thank Douglas Habliston and Stuart Paul for excellent technical assistance. Stuart Paul was sponsored by the Summer Student Program of the Miami Heart Institute. We also thank Dr. W. M. Benson of Boehringer-Ingelheim, Ridgefield, Conn., for dipyridamole.

This work was supported in part by U. S. Public Health Service grants HL22087 and HL21568, the Council for Tobacco Research-U. S. A., Inc., and the John A. Hartford Foundation, Inc.

\section{REFERENCES}

1. Freiman, D. G., J. Suyemoto, and S. Wessler. 1965. Frequency of pulmonary thromboembolism in man. N. Engl. J. Med. 272: 1278-1280.

2. Gryglewski, R. J., R. Korbut, and A. Ocetkiewicz. 1978. Generation of prostacyclin by lungs in vivo and its release into the arterial circulation. Nature (Lond.). 273: 765-767.

3. Moncada, S., R. Korbut, S. Bunting, and J. R. Vane. 1978. Prostacyclin is a circulating hormone. Nature (Lond.). 273: 767-768.

4. Gryglewski, R. J. 1979. Prostacyclin as a circulatory hormone. Biochem. Pharmacol. 28: 3161-3166.

5. Crutchley, D. J., T. E. Eling, and M. W. Anderson. 1978. ADPase activity of ịsolated perfused rat lung. Life Sci. 22: $1413-1420$.

6. Cooper, D. R., G. P. Lewis, G. E. Lieberman, H. Webb, and J. Westwick. 1979. ADP metabolism in vascular tissue, a possible thrombo-regulatory mechanism. Thromb. Res. 14: 901-914.

7. Dieterle, Y., C. Ody, A. Ehrensberger, H. Stalder, and A. F. Junod. 1978. Metabolism and uptake of adenosine triphosphate and adenosine by porcine aortic and pulmonary endothelial cells and fibroblasts in culture. Circ. Res. 42: 869-876.

8. Pearson, J. D., J. S. Carleton, A. Hutchings, and J. L. Gordon. 1978. Uptake and metabolism of adenosine by pig aortic endothelial and smooth-muscle cells in culture. Biochem. J. 170: 265-271.

9. Kolassa, N., K. Pfleger, and M. Tram. 1971. Species differences in action and elimination of adenosine after dipyridamole and hexobendine. Eur. J. Pharmacol. 13: 320-325.

10. Das, D. K., S. Das, and H. Steinberg. 1978. Uptake and metabolism of adenosine by the isolated rat lung. Fed. Proc. 37: 222. (Abstr.)

11. Ryan, J. W., A. Chung, L. C. Martin, and U. S. Ryan. 1978. New substrates for the radioassay of angiotensin converting enzyme of endothelial cells in culture. Tissue Cell. 10: 555-562.

12. Ryan, U. S., E. Clements, D. Habliston, and J. W. Ryan. 1978. Isolation and culture of pulmonary artery endothelial cells. Tissue Cell. 10: 535-554.

13. Gimbrone, M. A., and R. S. Cotran. 1975. Human vascular smooth muscle in culture. Lab. Invest. 33: 16-27.

14. Habliston, D. L., C. Whitaker, M. A. Hart, U. S. Ryan, and J. W. Ryan. 1979. Isolation and culture of endothelial cells from the lungs of small animals. Am. Rev. Respir. Dis. 119: 853-868.

15. Moncada, S., R. J. Gryglewski, S. Bunting, and J. R. Vane. 1976. An enzyme isolated from arteries transforms prostaglandin endoperoxides to an unstable substance that inhibits platelet aggregation. Nature (Lond.). 263: 663-665.

16. Baenziger, N. L., M. J. Dillender, and P. W. Majerus. 1977. Cultured human skin fibroblasts and arterial cells produce a labile platelet-inhibitory prostaglandin. Biochem. Biophys. Res. Commun. 78: 294-301.

17. Norman, G. A., M. J. Follett, and D. A. Hector. 1974. Quantitative thin-layer chromatography of ATP and the products of its degradation in meat tissue. J. Chromatogr. 90: $105-111$.

18. Shimizu, H., C. R. Creveling, and J. Daly. 1970. Stimulated formation of adenosine $3{ }^{\prime} 5^{\prime}$-cyclic phosphate in cerebral cortex: synergism between electrical activity and biogenic amines. Proc. Natl. Acad. Sci. U. S. A. 65: $1033-1040$.

19. Born, G. V. R., and M. J. Cross. 1963. The aggregation of blood platelets. J. Physiol. (Lond.). 168: 178-195.

20. Gordon, J. L., and J. D. Pearson. 1978. Effects of sulfinpyrazone and aspirin on prostaglandin $\mathrm{I}_{2}$ (prostacyclin) synthesis by endothelial cells. Br. J. Pharmacol. 64: $481-483$.

21. Czervionke, R. L., J. B. Smith, G. L. Fry, J. C. Hoak, and D. L. Haycraft. 1979. Inhibition of prostacyclin by treatment of endothelium with aspirin. J. Clin. Invest. 63: 1089-1092.

22. Glasgow, J. G., R. Schade, and F. A. Pitlick. 1978. Evidence that ADP hydrolysis by human cells is related to thrombogenic potential. Thromb. Res. 13: 255-266.

23. Dosne, A. M., C. Legrand, B. Bauvois, E. Bodevin, and J. P. Caen. 1978. Comparative degradation of adenylnucleotides by cultured endothelial cells and fibroblasts. Biochem. Biophys. Res. Commun. 85: 183-189.

24. Bloom, D. S., A. W. G. Cole, and T. N. Palmer. 1979. The protective action of inosine on isolated arteries in hypoxia. Br. J. Pharmacol. 65: 587-592.

25. Habliston, D. L., U. S. Ryan, and J. W. Ryan. 1978. Endothelial cells degrade adenosine-5'-diphosphate. J. Cell. Biol. 79: 206A. (Abstr.) 
26. Lieberman, G. E., G. P. Lewis, and T. J. Peters. 1977. A membrane-bound enzyme in rabbit aorta capable of inhibiting adenosine-diphosphate-induced platelet aggregation. Lancet. II: 330-332.

27. Ryan, J. W., and U. Smith. 1971. Metabolism of adenosine 5-monophosphate during circulation through the lungs. Trans. Ass. Amer. Physicians. 84: 297-306.

28. Rubio, V. R., T. Wiedmeier, and R. M. Berne. 1972 Nucleoside phosphorylase: localization and role in the myocardial distribution of purines. Am. J. Physiol. 222. $550-555$

29. Kubler, W., P. G. Spieckermann, and H. J. Bretschneider. 1970. Influence of dipyridamol (persantin) on myocardial adenosine metabolism. J. Mol. Cell. Cardiol. 1: 23-38.

30. Schrader, J., R. M. Berne, and R. Rubio. 1972. Uptake and metabolism of adenosine by human erythrocyte ghosts. Am. J. Physiol. 223: 159-166.

31. Pearson, J. D., and J. L. Gordon. 1979. Vascular endothelial and smooth muscle cells in culture selec- tively release adenine nucleotides. Nature (Lond.). 281: 384-386.

32. Best, L. C., M. B. McGuire, P. B. B. Jones, T. K. Holland, T. J. Martin, F. E. Preston, D. S. Segal, and R. G. G. Russell. 1979. Mode of action of dipyridamole on human platelets. Thromb. Res. 16: 367-379.

33. Rajah, S. M., M. J. Crow, A. F. Penny, R. Ahmad, and D. A. Watson. 1977. The effect of dipyridamole on platelet function: correlation with blood levels in man. Br. J. Clin. Pharmacol. 4: 129-133.

34. Moncada, S., and R. Korbut. 1978. Dipyridamole and other phosphodiesterase inhibitors act as antithrombotic agents by potentiating endogenous prostacyclin. Lancet. I: 1286-1289.

35. Born, G. V. R., and D. C. B. Mills. 1969. Potentiation of the inhibitory effect of adenosine on platelet aggregation by drugs that prevent its uptake. J. Physiol. (Lond.). 202: 41P. (Abstr.)

36. O'Grady, J., and S. Moncada. 1978. Aspirin: a paradoxical effect on bleeding-time. Lancet II: 780 . 